\title{
The Effects of EM (Effective Microorganisms) and Biochar on the Rate of Decomposition and the Nutrient Content of the Compost Manure Produced from the Locally Available Materials during Composting in Kakamega Central Sub County Kenya
}

\author{
Inviolata Nanyuli ${ }^{1, a,}{ }^{*}$, Stanley Omuterema ${ }^{1, b}$, Francis N. Muyekho ${ }^{2, c}$ \\ ${ }^{1}$ Department of Disaster Management and Sustainable Development Masinde Muliro University of \\ Science and Technology \\ ${ }^{2}$ Department of Agricultural Land use Management Masinde Muliro University of Science and \\ Technology \\ alusweti.invio@gmail.com, bomu2003@gmail.com, 'fnmuyekho57@gmail.com
}

Keywords: EM, Biochar, Berkeley Decomposing

\begin{abstract}
Kakamega County is one of the most densely populated regions in Kenya and most people are dependent on agriculture for their livelihood. High population has led to continuous cultivation hence depletion of nutrients through the removal of crop residues, leaching and soil erosion. Inorganic fertilizers can restore soil fertility but are unaffordable for the majority of smallholder farmers living with 1240 KES (10.32 EUR) per month. However, despite government and NGOs interventions towards promoting the use of organic fertilizers in Kakamega County, the adoption rates are still low due to the long waiting period before the compost manure is ready. This study aimed at solving the problem of the period taken by the locally available organic matter to decompose and consequently the quality of the compost manure produced from various treatments. The objective of the study was to examine the effects of EM and Biochar on the rate of decomposition of locally available organic materials under Berkeley composting technique; and to evaluate the nutrient content of compost manure produced from the different treatments. Experimental design was used to examine the effects of EM and Biochar on the rate of decomposition under Berkeley composting technique and to evaluate the nutrient content of compost manure produced from different treatments. Four treatments; (i) Normal Berkeley (Control) (ii) EM+Berkeley (iii) Biochar+Berkeley, and (iv) EM+Biochar+Berkeley were evaluated in a completely randomized block design replicated three times. Nutrient content analysis used; Wet chemistry, LDPSA, PXRF and Mid-infrared (MIR) spectroscopy. Berkeley Hot/Rapid composting was the most adopted composting technique $(28.65 \%)$, significance $\left(\chi^{2}=66.500\right)$. Combining Biochar and EM (T4) significantly $(\mathrm{P}<0.05)$ accelerated the rate of decomposition of organic matter by attaining the highest temperature of $60^{\circ} \mathrm{C}$ on the $4^{\text {th }}$ day, followed by compost heap with biochar alone (T3) and compost heaps with $\mathrm{EM}$ (T2) which attained the highest temperature of $58^{\circ} \mathrm{C}$ respectively on the $6^{\text {th }}$ day compared to compost piles without biochar or EM at a temperature of $55^{\circ} \mathrm{C}$ on $8^{\text {th }}$ day. The results suggest that Biochar and EM accelerate the composting process. $\mathrm{pH}$, total N, K and CEC were not significantly affected by the composting treatments, while Total Carbon was significantly $(p<0.05)$ highest in the Biochar+Berkeley treatment, followed by EM+Berkeley treatment and lowest in EM+Biochar+Berkeley treatment. Phosphorus and Total carbon were also higher in EM compost $(1.8 \%$ and $5.4 \%)(\mathrm{p}<0.05)$ compared to non-EM compost $(1.2 \%$ and $5.0 \%)$.
\end{abstract}

\section{Introduction}

The world population is growing and the United Nations expect there will be 8.9 billion people by 2050 . Most of these people will live in developing countries, where nowadays already $20 \%$ of the population is underfed or malnourished [1-2]. The demand for food will increase as well as the need to produce more food on declining arable land [1-2]. 
Agriculture remains the most important economic activity in Kenya, although less than $8 \%$ of the land is used for crop and feed production. Farming in Kenya is typically carried out by small producers who usually cultivate no more than two hectares (about five acres) using limited technology [3]. Kakamega County is one of the most densely populated counties of Kenya, with most people living in rural communities. The main economic activity is farming and people are directly dependent on locally grown crops or food harvested from the environment [4]. Traditionally, farmers relied on long fallow periods to restore soil fertility. However, the increased population has shortened the fallow periods and decreased the available arable land. Shifting cultivation disappeared and now crops are grown continuously on poor fields. Furthermore, farmers remove all crop residues from the field, using them as feed for their livestock or as fuel. They also use small amounts of inorganic fertilizers because they are unaffordable, resulting in a negative nutrient balance of the soil [5]. High rates of erosion, leaching and the inherent poor fertility of most tropical soils have also contributed to the soil fertility decline in Western Kenya [6].

Soil health ecosystem services on degraded lands can be supported by nutrient management strategies that recouple nitrogen, phosphorus and carbon cycling within the agro-ecosystem. The use of compost or organic manure is currently being advocated as an option for improving soil fertility conditions for resource poor farmers.

Key Agricultural stakeholders in Kakamega county are encouraging and educating farmers to use various techniques in composting among which include Berkeley rapid and use of Inoculation technologies like EM [1]. Despite government and NGOs interventions towards promoting the use of organic fertilizers, there is a challenge of low adoption due to the long waiting period before the compost manure is ready for use [7]. This strategy aims to promote use of organic matter as the key source of fertilizers, which results into increased land fertility (8). This study examined the effects of EM and Biochar on the rate of decomposition of locally available materials under Berkeley composting technique decompose and consequently the quality of the compost manure produced from various treatments.

\section{Literature Review}

\subsection{Berkeley rapid composting method - shredding and frequent turning}

This method corrects some of the problems associated with the earlier methods of composting [9]. The process can produce compost in two to three weeks. Several factors are essential to the rapid composting method: Material composts best when it is $1.25-3.75 \mathrm{~cm}$ in size. Soft, succulent tissues do not need chopping into very small pieces because they decompose rapidly. The harder or woodier the tissues, the smaller they need to be in order to decompose rapidly. Woody material should be passed through a grinder. Chopping material with a sharp shovel is effective for the composting process to work most effectively (10). The material to be composted should have a C:N ratio of 30:1. Mixing equal volumes of green plant material with equal volumes of naturally dry plant material yields such a ratio. The green material can be grass clippings, old flowers, green prunings, weeds, fresh garbage and fruit and vegetable wastes. The dried material can be fallen leaves, dried grass, straw and woody materials from prunings. Materials that should not be added to a composting pile include: soil, ashes from a stove or fireplace, and manure from carnivorous animals. Manures from herbivorous animals such as rabbits, goats, cattle, horses, elephants and fowl can be used [11].

Once a pile has been started, nothing should be added. This is because it takes a certain length of time for the material to break down and anything added has to start at the beginning, thus lengthening the decomposition time for the whole pile. Excess material should be as dry as possible during storage until a new pile is started. Moist stored materials start to decompose. If this occurs, they will not be effective in the compost pile. Nothing needs to be added to the organic materials to make them decompose. The micro-organisms active in the decomposition process are ubiquitous where plant materials are found and develop rapidly in any compost pile [11]. 
Composting works best where the moisture content of materials in the pile is about 50 percent. Too much moisture creates a soggy mass, and decomposition will then be slow and the pile will smell. Where the organic material is too dry, decomposition is either very slow or does not occur at all. Heat, which is very important in rapid composting, is supplied by the respiration of the micro-organisms as they break down the organic materials. To prevent heat loss and to build up the amount of heat necessary, a minimum volume of material is essential [10].

\subsection{EM-based compost enhancers}

Effective micro-organisms (EM) consist of common and food-grade aerobic and anaerobic micro-organisms: photosynthetic bacteria, lactobacillus, Streptomyces, actinomycetes, yeast, etc. The strains of the micro-organisms are commonly available from microbe banks or from the environment. There are no genetically engineered strains that are in use. Since 1999, seven smallscale organic fertilizer units have been using the EM-based quick production process in Myanmar [10].

EM solution is prepared by mixing $10 \mathrm{ml}$ of EM, $40 \mathrm{ml}$ of molasses and $950 \mathrm{ml}$ of water and leaving it for five to seven days, depending on temperature. The solution is then added to 1 litre of molasses and 98 litres of water to obtain 100 litres of ready-to-use EM solution. This amount is enough for three pits. The EM solution functioning as accelerator reduces the composting period from three months to one month. Critique of EM is that not so many smallholder farmers have the knowledge of preparing it.

\subsection{Biochar Compost enhancers}

Biochar is defined as charcoal that is used for agricultural purposes. It is created using a pyrolysis process, heating biomass in a low oxygen environment. Once the pyrolysis reaction has begun, it is self-sustaining, requiring no outside energy input. Byproducts of the process include syngas $\left(\mathrm{H}_{2}+\mathrm{CO}\right)$, minor quantities of methane $\left(\mathrm{CH}_{4}\right)$, tars, organic acids and excess heat [10].

Biochar can be an important tool to increase food security and cropland diversity in areas with severely depleted soils, scarce organic resources, and inadequate water and chemical fertilizer supplies [12]. Biochar also improves water quality and quantity by increasing soil retention of nutrients and agrochemicals for plant and crop utilization. More nutrients stay in the soil instead of leaching into groundwater and causing pollution. Biochar is a relatively recent development, emerging in conjunction with soil management issues [12].

Biochar, produced from high carbon content solid biomass, is one of the best bulking agents for reducing $\mathrm{N}_{2} \mathrm{O}$ emission in manure composting for the following reasons (10). First of all, its high porosity results in increased aeration in the composting process, which enhances the supply and distribution of $\mathrm{O}_{2}$ in the composting pile, and may lead to reduction of $\mathrm{N}_{2} \mathrm{O}$ as previously mentioned reasons [13]. Secondly, the high porosity and high surface area of biochar also enables it to absorb and retain large amounts of water which results in decreased $\mathrm{N}_{2} \mathrm{O}$ emission by altering redox conditions and denitrifying communities. High moisture content also enhances the metabolic activities of microorganisms [14-15]. Furthermore, other recent studies confirmed that bulking poultry manure with biochar lessened $\mathrm{N}$ loss and improved $\mathrm{N}$ retention, while simultaneously enhanced humification, thereby produced mature composts with a high fertilizer value [16-18]. Fourthly, biochar with a higher $\mathrm{pH}$ alters the abundance of denitrifying bacteria significantly in manure composting, resulting in less $\mathrm{N}_{2} \mathrm{O}$ producing but more $\mathrm{N}_{2} \mathrm{O}$-consuming bacteria communities [14].

\section{Material and Methodology}

\subsection{Study Site}

The field experiments were conducted in Kakamega central sub-county, Kakamega County, Kenya. Kakamega is situated $0^{\circ} 12^{\prime} \mathrm{N} ; 34^{\circ} 48^{\prime} \mathrm{E}$ at an elevation of $1,250 \mathrm{~m}$ above sea level in the southwest and 2,000 $\mathrm{m}$ in the east. Annual mean temperature varies between 18 to $21^{\circ} \mathrm{C}$ and annual 
rainfall varies between 1,000 and $2,400 \mathrm{~mm}$. There are two yearly rain seasons: the long rains, from March until June, and the short rains from August until November. About 500 to 1,100 mm falls during the long rains and 450 to $850 \mathrm{~mm}$ during the short rains. The rainy season is characterized by heavy afternoon showers with occasional thunderstorms. Soils in Kakamega are highly weathered and vary in texture from clay to sandy loam. However, due the heavy rains, soils are vulnerable to erosion leading to a reduced agricultural productivity. Therefore, $70 \%$ of the soils are low in fertility due the intensive weathering, leaching and continuous cultivation without using fertilizers [19].

According to the 2009 population census report, the total population of people in Kakamega County is 1,660,651 (male-48\% and female-52\%) and an area of 3,2444km while in Urban Kakamega is 58,832 with a population density of $515 \mathrm{Sq} . \mathrm{Km}$. It has an annual growth rate of $2.12 \%$. Poverty level is at 57\% as compared to Nationals level of 51\%, Fig. 3.1 illustrates the study area.

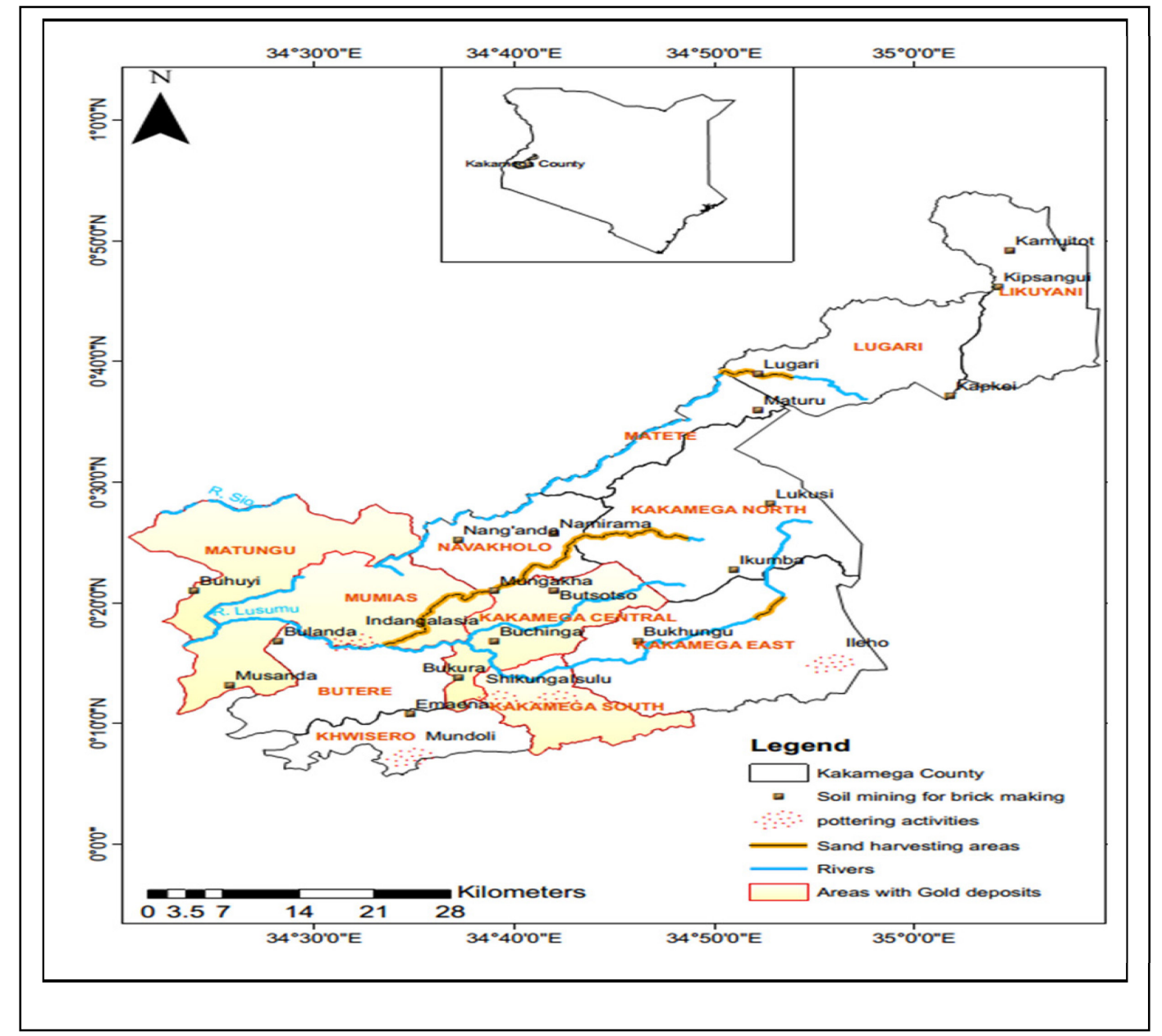

Figure 3.1. Study area map.

\subsection{Research design and Data collection}

Experimental research design was used to Examine the effects of EM and Biochar on the rate of decomposition and the nutrient content of the compost manure, of the locally available materials during composting in Kakamega Central sub county Kenya .

The On-station experiments were laid out in completely randomized block design with three [3] replications. The experiments were carried out during the short rains (September to November), 2016, at the Masinde Muliro University of Science and Technology (MMUST) School of Agriculture and Veterinary Sciences and Technology field trials. The treatments were (i) Normal Berkeley with No additions (Control), (ii) EM + Organic matter under Berkeley composting method, (iii) Biochar + Organic matter under Berkeley composting method and (iv) EM + Biochar + Organic matter under Berkeley composting method. 
The compost heap was built by alternating Carbon and Nitrogen sources until a height of $1.5 \mathrm{M}$ was attained. The ratio of Carbon to Nitrogen was maintained at 30:1. Water was added, aiming for 50 percent moisture content. This was achieved by spraying each layer with water mixed with EM using a watering can while layering compost materials. However, care was taken so that the water does not become excess as it may make the compost water logged and smelly. The compost heap size was $1 \mathrm{M}$ by $1 \mathrm{M}$ by $1.5 \mathrm{M}$ and this was manageable size to be able to generate enough heat for decomposition to occur.

First turning was done on the fourth $\left(4^{\text {th }}\right)$ day after building the compost heap. Subsequent turnings were done after every two (2) days until the compost was ready. Turning was done by putting the outside material from the pile into the middle and vice versa. Temperatures were taken using a thermometer from the first day and throughout the subsequent turnings. Finally compost with different treatments was attained within 21 days.

To determine the nutrient content of compost manure produced from different treatments under Berkeley composting technique, Compost manure samples from the four treatments, replicated three (3) times were taken for analysis at the World Agroforestry Centre(ICRAF), Nairobi; Soil and Plant Spectral Diagnostic Laboratory and Crop Nutrition Soil and Plant Laboratory. Determination of the Moisture content (Oven drying at $70^{\circ} \mathrm{C}$ for $48 \mathrm{hrs}$ ) of the initial organic materials that were used to make the compost heaps was done at MMUST. Chemical analysis of both the initial organic materials that were used to make the compost heaps and the compost manure itself was done. A total of 53 compost manure samples and 8 plant samples were collected. Before the compost manure samples of specified treatments were taken, each compost heap was thoroughly mixed using the pitch forks. Each of the compost manure sample of specified treatments at specified days were taken with a spade at $(0-20 \mathrm{~cm})$ from the top, bottom and on both sides of the compost heap. This was then put into a small basin and thoroughly mixed. Double quartering was then used to obtain composite sample for each treatment on the specified day. Samples at the Laboratory were then air dried on shallow trays for two days before analysis was done.

Chemical and Physical parameters of the compost determined included: Carbon content of acid treated sample to remove carbonates, Nitrogen content of acid treated sample to remove carbonates, Total Carbon content, Total Nitrogen content, Soil pH in water (soil: water ratio of 1:2 weight to volume basis), Exchangeable Aluminium concentration by Mehlich III extraction, Boron concentration by Mehlich III extraction, Exchangeable calcium concentration by Mehlich III extraction, Copper concentration by Mehlich III extraction, Iron concentration by Mehlich III extraction, Potassium concentration by Mehlich III extraction, Exchangeable Magnesium by wet chemistry method, Exchangeable Manganese concentration by Mehlich III extraction, Exchangeable Sodium concentration by Mehlich III extraction, Phosphorus by Mehlich III extraction, Sulphur by Mehlich III extraction, Zinc by Mehlich III extraction, Sodium total element concentration, Magnesium total element concentration, Sulfur total element concentration, Chlorine total element concentration, Potassium total element concentration, Particle size analysis, CEC and EC.

\section{Results}

\subsection{Temperature changes under the four different Treatments under Berkeley composting technique}

The four treatments include: (i) Normal Berkeley with No additions (Control)-T1; (ii) EM + Organic matter under Berkeley composting method-T2; (iii) Biochar + Organic matter under Berkeley composting method-T3 and (iv) EM + Biochar + Organic matter under Berkeley composting method-T4. Temperature results for the four treatments replicated three times are as shown in Fig. 4.1, Tables 4.1 and 4.2. 


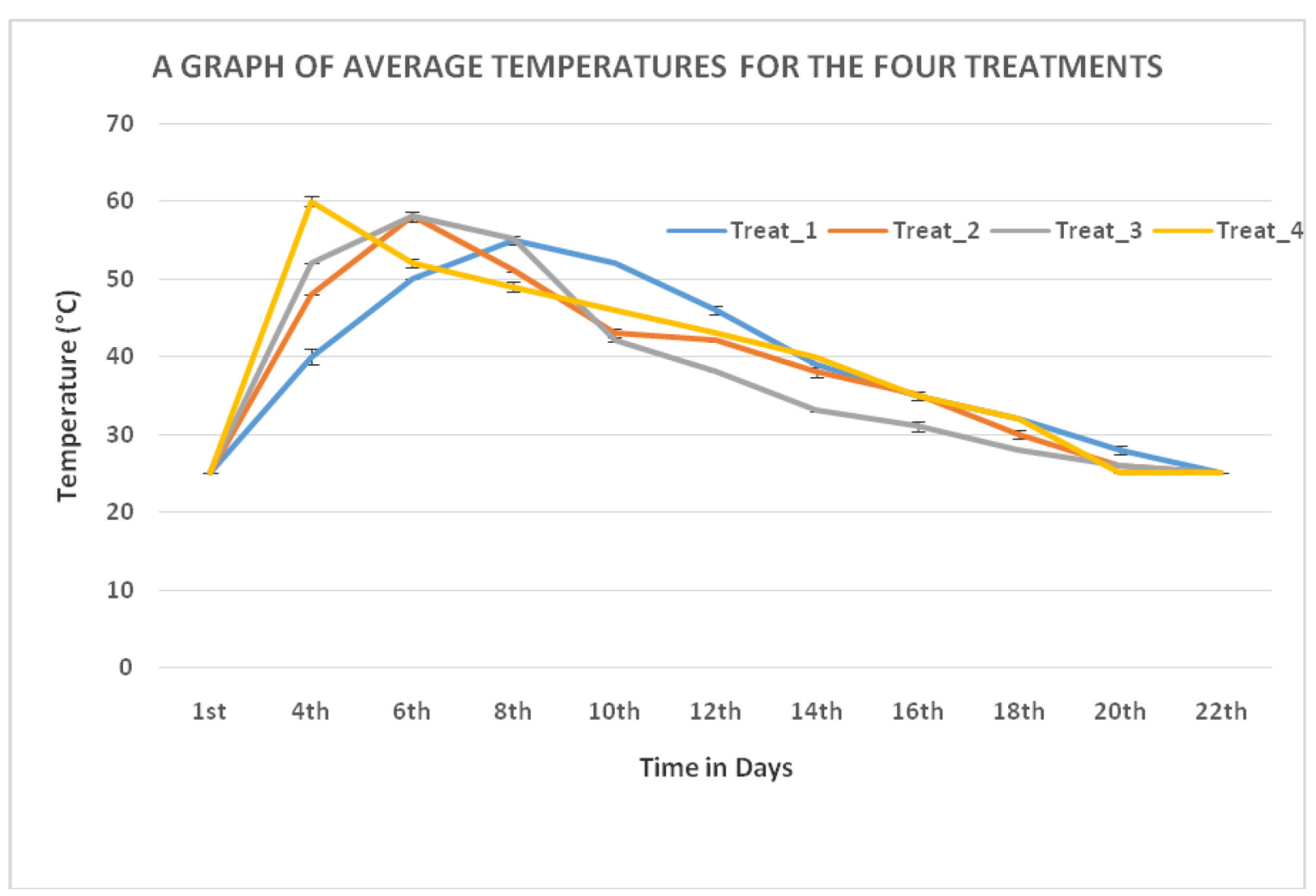

Figure 4.1. Temperature Verses Time in days for the four treatments under Berkeley composting technique with the Error Bars and Standard deviation for the On-station experiments

Under normal Berkley composting (Treat1), the temperature recorded on the first day was $25{ }^{\circ} \mathrm{C}$, on the fourth day which was also the first turning; the temperature had reached $40^{\circ} \mathrm{C}$. The highest temperature $\left(55^{\circ} \mathrm{C}\right)$ was attained on the $8^{\text {th }}$ day which is also the $3^{\text {rd }}$ turning. When comparing composting with EM (Treat 2) and normal Berkley (Treat 1); both treatments show an increase in temperature right after composting started. On Day 1, the temperature rose to $48^{\circ} \mathrm{C}$ from $25^{\circ} \mathrm{C}$ for treatment with EM (Treat 2) and $40^{\circ} \mathrm{C}$ from $25^{\circ} \mathrm{C}$ for treatment without EM (Treat 1). The piles treated with $\mathrm{EM}$ reached the highest peak values of $58^{\circ} \mathrm{C}$ on Day 6 compared to composting treatment without $\mathrm{EM}$, for which it was $55^{\circ} \mathrm{C}$ on Day 8 . Composting with addition of Biochar showed temperature increase from $25^{\circ} \mathrm{C}$ on the first day to $52^{\circ} \mathrm{C}$ on the $4^{\text {th }}$ day. The highest temperature of $58^{\circ} \mathrm{C}$ for piles with Biochar was attained on the $6^{\text {th }}$ day. Under composting with both Biochar and $\mathrm{EM}$, temperature increased from $25^{\circ} \mathrm{Con}$ the first day to $60^{\circ} \mathrm{C}$ on the $4^{\text {th }}$ day/first turning. This was the highest temperature attained on the $4^{\text {th }}$ day unlike under normal Berkley composting where the highest temperature $55^{\circ} \mathrm{C}$ was attained on the $8^{\text {th }}$ day. The results show the importance of combining Biochar and EM in enhancing composting process. 


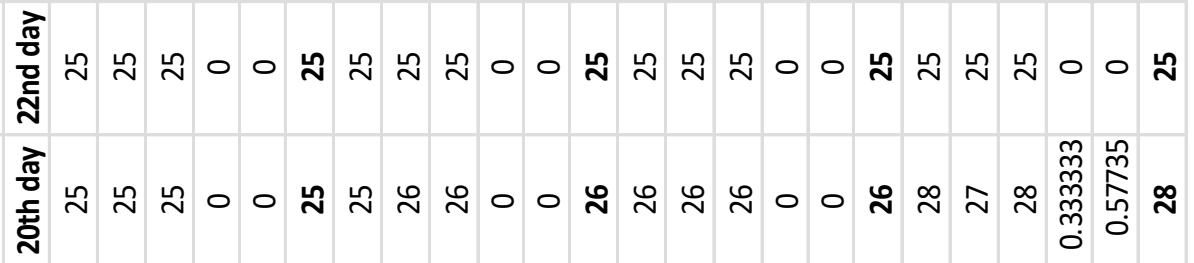

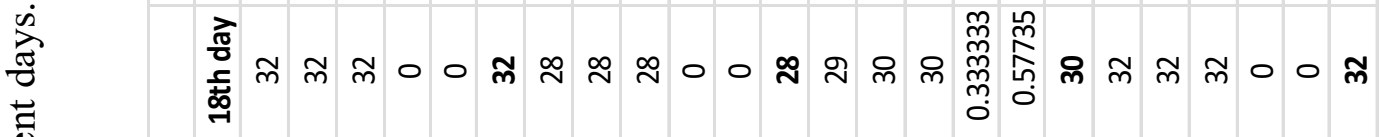
要

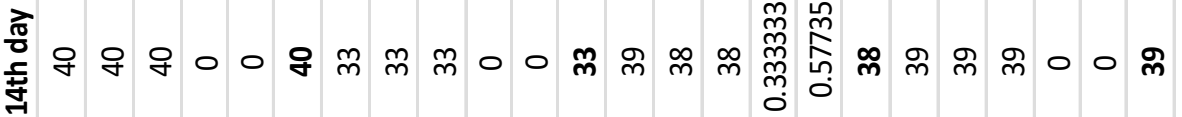

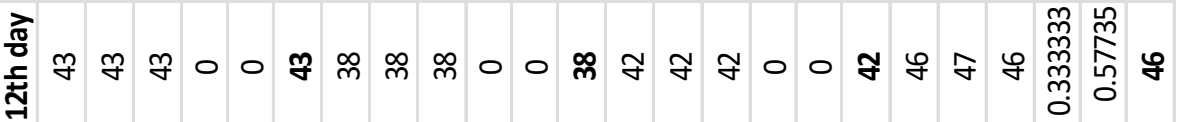

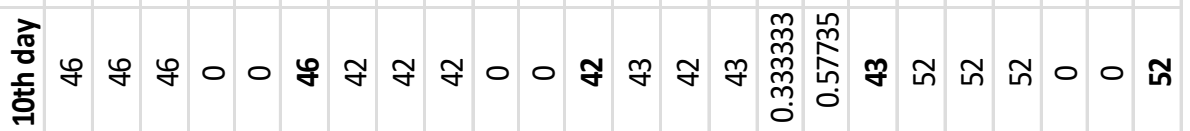

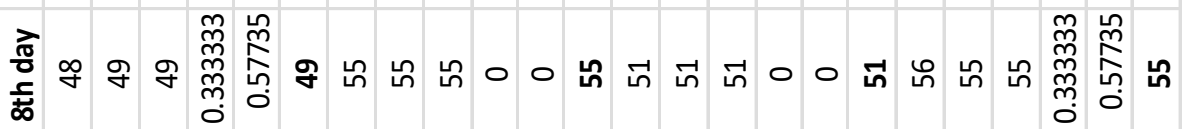
超

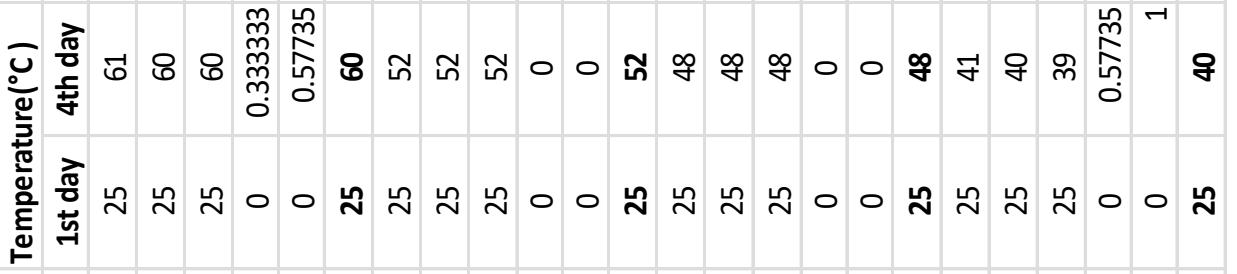

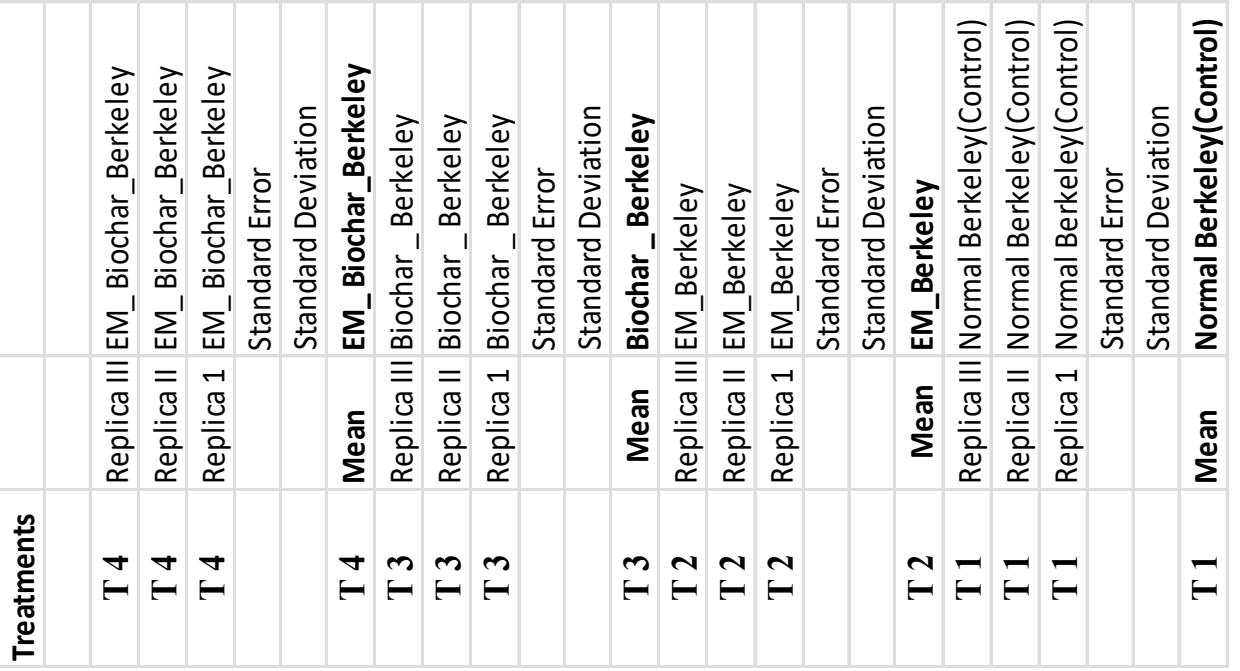


Shapiro Wilk test was done to test for Normality of the data. R software version 3.2.4 was used; $w=0.96743, p=0.1091$ hence $p>0.05$. This means distribution of data are not significantly different from Normal distribution hence assuming normality. Parametric Two-way Analysis of Variance (ANOVA) using SAS version 6.12 was then used. Table 4.2 shows the results of effects on temperatures as days progressed during composting.

Table 4.2. The results of effects on temperatures as days progressed during composting.

\begin{tabular}{|c|c|c|c|c|c|c|c|c|c|}
\hline \multirow[t]{2}{*}{ Treatments } & \multicolumn{5}{|c|}{ Time in Days } & \multirow[b]{2}{*}{$14^{\text {th }}$} & \multirow[b]{2}{*}{$16^{\text {th }}$} & \multirow[b]{2}{*}{$18^{\text {th }}$} & \multirow[b]{2}{*}{$20^{\text {th }}$} \\
\hline & $4^{\text {th }}$ & $6^{\text {th }}$ & $8^{\text {th }}$ & $10^{\text {th }}$ & $12^{\text {th }}$ & & & & \\
\hline Normal Berkeley & $40.00 \mathrm{~d}$ & $50.00 \mathrm{c}$ & 55.33aa & $52.00 \mathrm{a}$ & $46.33 a$ & $39.00 \mathrm{~b}$ & $35.33 \mathrm{aa}$ & $32.00 \mathrm{a}$ & $27.67 \mathrm{a}$ \\
\hline EM_Berkeley & $48.00 \mathrm{c}$ & $58.33 \mathrm{a}$ & $51.00 \mathrm{~b}$ & $42.67 \mathrm{c}$ & $42.00 \mathrm{c}$ & $38.33 \mathrm{c}$ & $35.00 \mathrm{a}$ & $29.67 \mathrm{~b}$ & $26.00 \mathrm{bb}$ \\
\hline Biochar_Berkeley & $52.00 \mathrm{~b}$ & 58.33aa & $55.00 \mathrm{a}$ & $42.00 \mathrm{~d}$ & $38.00 \mathrm{~d}$ & $33.00 \mathrm{~d}$ & $30.67 \mathrm{~b}$ & $28.00 \mathrm{c}$ & $25.67 \mathrm{bc}$ \\
\hline EM_Bioch_Berkeley & y 60.33a & $51.67 \mathrm{~b}$ & $48.67 \mathrm{c}$ & $46.00 \mathrm{~b}$ & $43.00 \mathrm{~b}$ & $40.00 \mathrm{a}$ & $35.33 \mathrm{aa}$ & 32.00aa & $25.00 \mathrm{c}$ \\
\hline C.V & 1.07 & 0.97 & 0.83 & 0.65 & 0.71 & 0.80 & 1.55 & 0.98 & 1.57 \\
\hline L.S. D & 1.03 & 1.02 & 0.84 & 0.58 & 0.58 & 0.58 & 1.02 & 0.58 & 0.79 \\
\hline
\end{tabular}

Treatments having the same letters within a column are not significantly different with ANOVA T test at $\mathrm{p}<0.05$

From the results (Tables $4.1 ; 4.2$ and Fig. 4.1); On the $4^{\text {th }}$ day, which was also the $1^{\text {st }}$ turning, all the treatments were significantly $(\mathrm{p}<0.05)$ different from each other with EM-Biochar-Berkeley recording the highest peak mean temperatures of $60.33^{\circ} \mathrm{C}$. This shows that EM-Biochar-Berkeley reached thermophilic stage on day 4.

On the $6^{\text {th }}$ day, which was also the $2^{\text {nd }}$ turning, EM-Berkeley and Biochar-Berkeley treatments were significantly $(\mathrm{p}<0.05)$ highest, (and their peak) than the rest of the treatments (Mean temperatures of $58.33^{\circ} \mathrm{C}$ ). It shows that they reached the thermophilic stage on day 6 .

Day 8 shows Normal Berkeley being significantly $(p<0.05)$ highest (at its peak) than the rest of the treatments. It was attaining this temperature on the $3^{\text {rd }}$ turning.

Day 10 shows the temperatures dropping for all the treatments but they remain significantly different $(p<0.05)$. On day 16 which is also the $7^{\text {th }}$ turning, temperatures for all the treatments have steadily reduced significantly $(\mathrm{p}<0.05)$ and Normal Berkeley and EM-Biochar-Berkeley treatments recorded the same mean temperature of $35.33^{\circ} \mathrm{C}$ as they stabilize to the ambient temperatures. 


\subsection{Nutrient contents of organic materials and compost manure from different treatments under Berkeley technique in Kakamega central sub-county, Kenya}

Table 4.3. Chemical and physical properties of locally available organic materials that were used to make the compost heaps in Kakamega central sub county, Kenya.

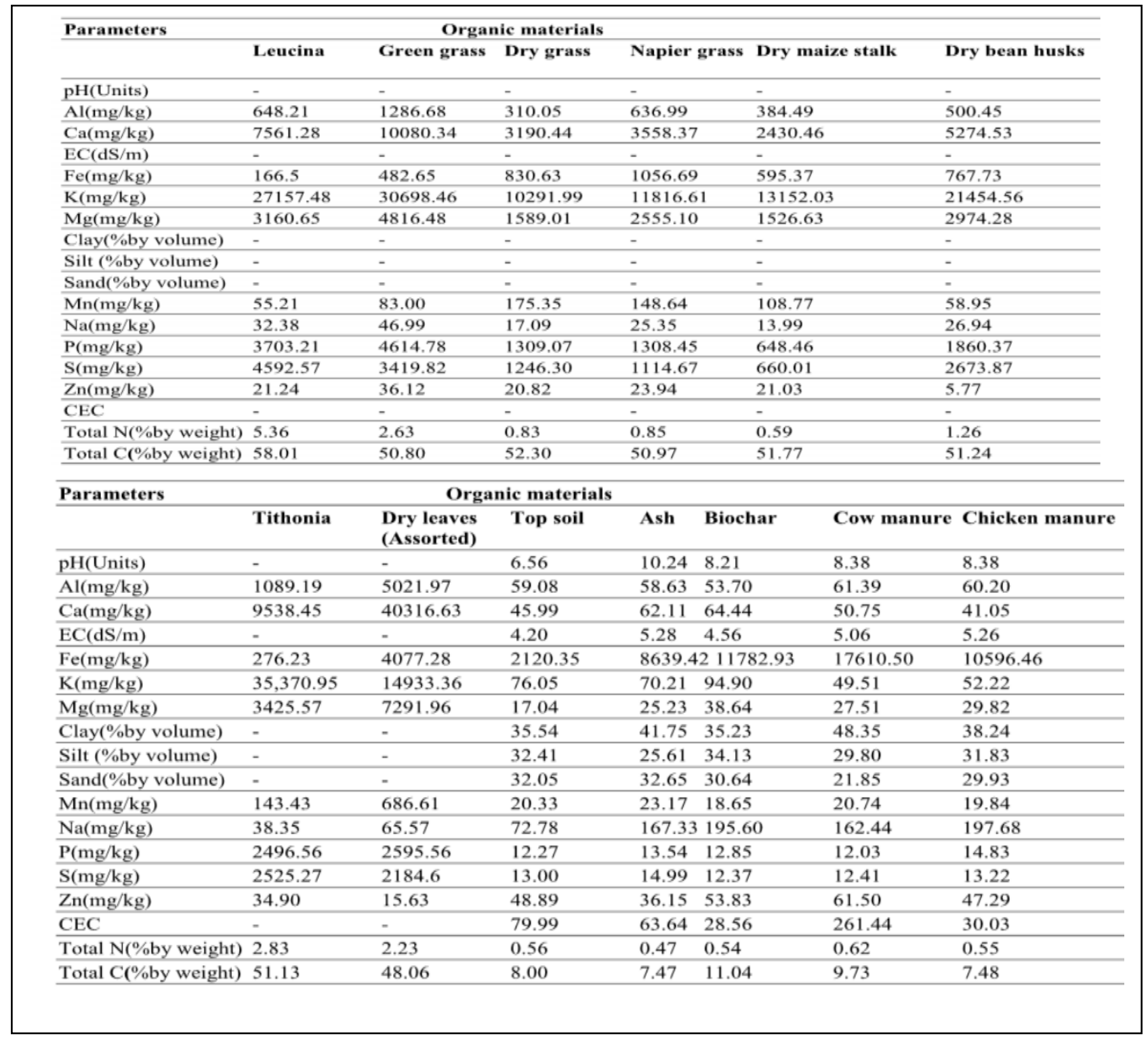

The results in Table 4.3 above shows heterogeneity of organic residues, nutrient and physical and chemical properties vary widely, even among materials from the same origin. The nutrient content of plant residues ranged, for $\mathrm{N}, \mathrm{P}, \mathrm{K}, \mathrm{Ca}, \mathrm{Mg}, \mathrm{Cu}, \mathrm{Mn}$, and $\mathrm{Zn}$, respectively: $11-73 \mathrm{~g} \mathrm{~kg}^{-1}$, 1-29 $\mathrm{g} \mathrm{kg}^{-1}, 5-38 \mathrm{~g} \mathrm{~kg}^{-1}, 4-54 \mathrm{~g} \mathrm{~kg}^{-1}, 1-6 \mathrm{~g} \mathrm{~kg}^{-1}, 23-18 \mathrm{mg} \mathrm{kg}^{-1}, 23-29 \mathrm{mg} \mathrm{kg}{ }^{-1}$, and 70-298 $\mathrm{mg} \mathrm{kg}^{-1}$. The nutrient content ranges of animal origin materials presented are, respectively, for $\mathrm{N}, \mathrm{P}, \mathrm{K}, \mathrm{Ca}$, $\mathrm{Mg}, \mathrm{S}, \mathrm{Zn}, \mathrm{Mn}$ and $\mathrm{Cu}: 11-54 \mathrm{~g} \mathrm{~kg}^{-1}, 1-42 \mathrm{~g} \mathrm{~kg}^{-1}, 3-49 \mathrm{~g} \mathrm{~kg}^{-1}, 5-153 \mathrm{~g} \mathrm{~kg}^{-1}, 2.6$ to $14 \mathrm{~g} \mathrm{~kg}^{-1}$, 0.9-8 $\mathrm{g} \mathrm{kg}^{-1}, 48-1189 \mathrm{mg} \mathrm{kg}^{-1}, 340-2055 \mathrm{mg} \mathrm{kg}^{-1}$, and $15-1388 \mathrm{mg} \mathrm{kg}^{-1}$.

Characteristics of plant residues vary depending on the plant species, plant tissues, and soil chemical and physical properties, but are generally nutrient-poor and have lower EC than animal or municipal wastes [20]. 
Table 4.4. Effects of EM and Biochar on the chemical and Physical properties of the compost manure in Kakamega central sub county, Kenya

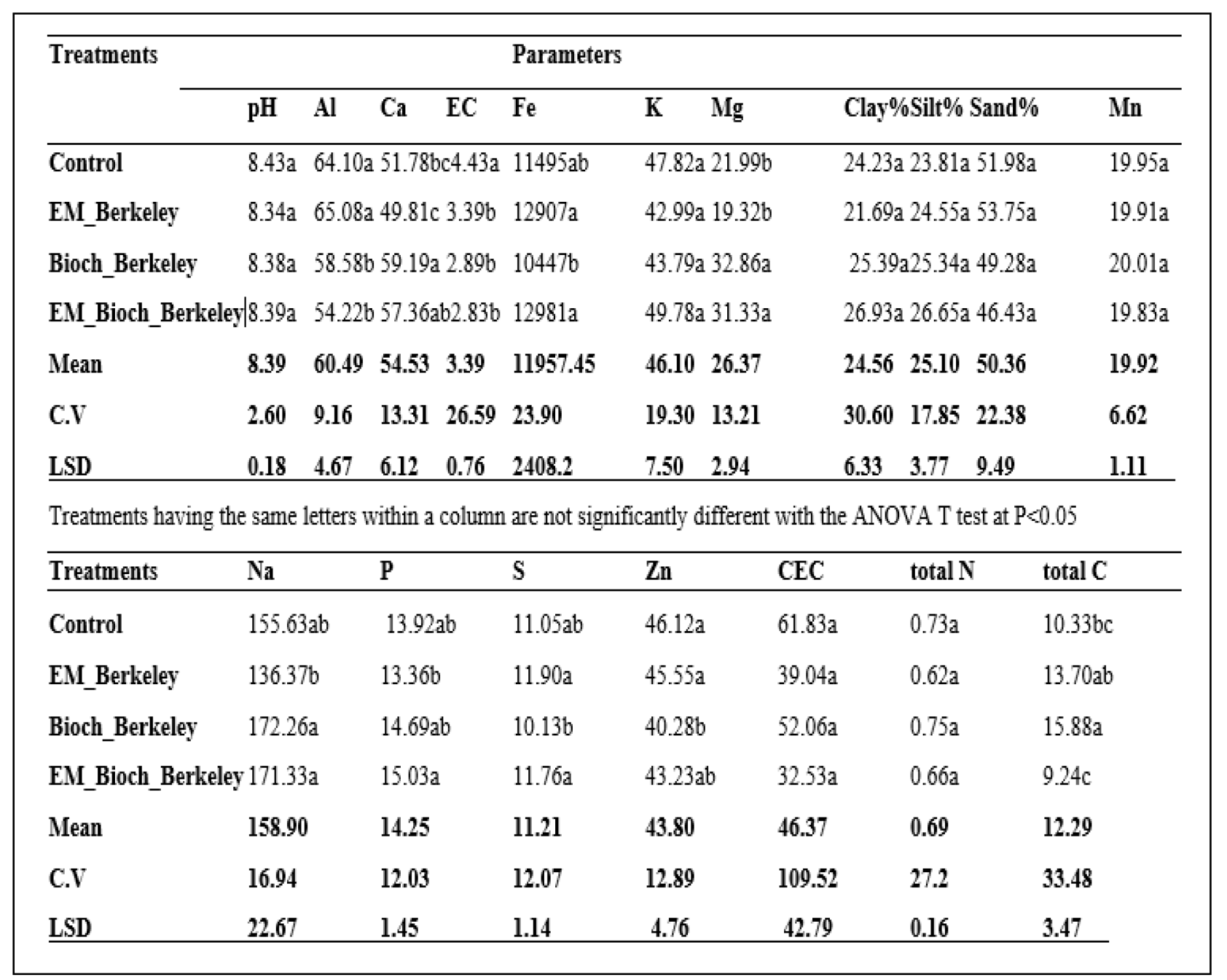

From Table 4.4, pH was not significantly different across the four treatments. This could be attributed to the fact that $\mathrm{pH}$ varies with the raw material used in the compost and the production of various products (lactic and acetic acids) during the composting period. During the thermophilic stage, $\mathrm{pH}$ can rise up to 9 and thereby releasing $\mathrm{NH}_{3}$. In the maturation stage, $\mathrm{pH}$ will drop to neutral [21].

Nitrogen was not significantly different in all the treatments. The reason could be attributed to the organic materials that were used to make the compost heaps for the treatments were all the same. Total Carbon was significantly $(\mathrm{p}<0.05)$ highest in the Biochar-Berkeley treatment, followed by EM-Berkeley treatment and lowest in EM-Biochar-Berkeley treatment. Total Carbon mean value was $12.29 \mathrm{mg} / \mathrm{kg}$. The EM's phototrophic bacteria are involved in various metabolic systems that play a major role in nitrogen cycle and carbon cycle [22].

$\mathrm{P}$ was significantly $(\mathrm{p}<0.05)$ higher in the EM-Biochar-Berkeley treatment as compared to the control (Normal Berkeley). Available K was not significantly different with the use of EM, and Biochar in the compost heaps when compared to the control experiment. CEC was not significantly different across all the treatments though it was lower in EM-Biochar-Berkeley treatment $(32.53 \mathrm{ds} / \mathrm{m})$. Particle size analysis (Sand, Clay and Silt percentages) was not significantly different within all the treatments as the texture was Sandy-clay-loam all through. EC was significantly $(\mathrm{p}<0.05)$ lowest in EM-Biochar-Berkeley treatment as compared to the rest of the treatments as well as $\mathrm{Al}$ that was significantly $(\mathrm{p}<0.05)$ lowest in EM-Biochar-Berkeley treatment. $\mathrm{Mg}$ and Fe were significantly $(\mathrm{p}<0.05)$ highest in EM-Biochar- Berkeley as compared to the control. 


\section{Discussion}

Normal Berkeley composting (T1) process matched the typical relationship between temperature and time that is present in typical compost [23]. There is an initial peak of temperature (of $55^{\circ} \mathrm{C}$ ) and this is the temperature when the Pathogens are normally destroyed. That temperature was attained on the 8th day, and this was the active phase. However, it's recommended that, peak temperatures of $62{ }^{\circ} \mathrm{C}$ are critical for elimination of weed seeds and this was not recorded under Normal Berkeley composting treatments. Farmers practicing normal Berkley may have some challenges of weeds on their farms when using the ready compost manure because it couldn't reach the highest temperature required to eliminate the weeds.

The piles treated with EM reached the highest peak values of $58^{\circ} \mathrm{C}$ on Day $6 . \mathrm{T} 2$ had the longest period of time above $55^{\circ} \mathrm{C}$, that is, from $2^{\text {nd }}$ turning to $3^{\text {rd }}$ turning. This clearly indicates, that the compost heaps with EM had high microbial activity compared to (T1) based on the highest temperatures achieved. Effective Micro-organisms (EM) enhances the rate of decomposition of organic materials. EM is a liquid containing many coexisting microorganisms: lactic acid bacteria, yeast and phototrophic bacteria. When these organisms are placed in contact with organic matter, they secrete substances such as vitamins, organic acids, minerals and antioxidants that beneficially affect plants and other micro-organisms [24].

The peak temperature of $58^{\circ} \mathrm{C}$ was attained on the $6^{\text {th }}$ day for piles with Biochar. This can be attributed to the ability of Biochar to accelerate the composting process. Biochar is commonly defined as charred organic matter, produced with the intent to deliberately apply to soils to sequester carbon and improve soil properties [12]. Biochar improves the homogeneity and structure of the mixture and stimulating microbialactivity in the composting mix. This increased activity translates to increased temperatures and a shorter overall time requirement for compost development. Increasing the use of biochar in compost operations requires education on the benefits of biochar to compostproducers, not only on emissions and odor reductions, but also on the potential economic benefits of accelerating the decomposition of organic matter.

Under T4(Biochar-EM-Berkeley), temperatures increased from $25^{\circ} \mathrm{C}$ on the first day to $60^{\circ} \mathrm{C}$ on the $4^{\text {th }}$ day, which was also $\left(1^{\text {st }}\right)$ first turning. This was the highest temperatures attained comparing all the four treatments (T1, T2, T3 and T4). Temperatures were stabilizing on day $14^{\text {th }}$ which was also the $6^{\text {th }}$ turning. The results clearly show the importance of combining Biochar and EM in accelerating the rate of decomposition of organic matter under Berkeley composting technique. Biochar has high porosity which results in increased aeration in the composting process, which enhances the supply and distribution of $\mathrm{O}_{2}$ in the composting pile \& provides energy for the microorganisms feeding on the organic matter [13]. Effective micro-organisms (EMs) on the other hand, reduces decomposition period significantly. Therefore, a mixture of EM with Biochar fastened the rate of decomposition.

Chemical and physical properties of locally available organic materials that were used to make the compost heaps varied widely even among materials from the same origin. Characteristics of plant residues vary depending on the plant species, plant tissues, and soil chemical and physical properties, but are generally nutrient-poor and have lower EC than animal or municipal wastes [20].

Mean $\mathrm{pH}$ of the compost manures produced was 8.39 . Soil $\mathrm{pH}$ reflects the acidity or alkalinity of the soil and controls many chemical processes but especially affects plant nutrient availability. Acid soils contain toxic concentrations of $\mathrm{Al}$ and/or $\mathrm{Mn}$ in the soil solution, which can restrict root and plant growth. Some plant nutrients like $\mathrm{P}$ are less available in acid soils due to precipitation with $\mathrm{Al}$ and $\mathrm{Fe}$ ions [25]. Microbial activity is optimal when $\mathrm{pH}$ ranges between 6.5 and 8 . However, bacteria need a pH between 6 and 7.5 whereas fungi need a $\mathrm{pH}$ between 5.5 and 8.9 for their activity. The $\mathrm{pH}$ varies with the raw material used in the compost and the production of various products (lactic and acetic acids) during the composting period.

$\mathrm{Fe}, \mathrm{Mn}, \mathrm{Cu}, \mathrm{Zn}, \mathrm{B}$, and Mo are essential elements for crop production and food quality. Applying organic matter to the soil can either decrease or increase metal availability, solubility, and plant uptake. Many organic amendments have a soluble $\mathrm{C}$ component or produce soluble decomposition products, which can increase metal solubility by forming soluble organometallic 
complexes. Micronutrients are also released through the biodegradation of OM by micro-organisms [26]. Soil structure and soil aggregate stability improve with increased SOM, because OM binds mineral particles (sand, silt and clay) together. This could be a result of the increased microbial activity and their synthesized products, like polysaccharides.

Total Carbon mean value was $12.29 \mathrm{mg} / \mathrm{kg}$. The EM's phototrophic bacteria are involved in various metabolic systems that plays a major role in nitrogen cycle and carbon cycle [22], [27]. This explains why Total Carbon was lowest in the EM-Biochar- Berkeley treatment though still adequate for the plant requirements. Increase of soluble $\mathrm{N}, \mathrm{P}$ and $\mathrm{K}$ contents could be attributed to activity of nitrogen fixers and organic acids excreted by the different organisms in EM. According to Saravanan et al. [28], macronutrient Nitrogen in EM compost is higher (1.2\%) compared to non-EM compost $(0.9 \%)$. Phosphorus and Total carbon was also higher in EM compost $(1.8 \%$ and $5.4 \%)$ compare to non-EM compost $(1.2 \%$ and $5.0 \%)$. Besides, the number of Potassium $(\mathrm{K})$ is increased in compost added with EM (55\%) compared to in compost without EM (17\%) [29].

Generally, compost treated with EM resulted in low quantities of heavy metals. This is because natural process which relies on bacteria, fungi, and plants alter contaminants such heavy metals as these organisms carry out their normal life functions. Metabolic processes of these organisms are capable of using chemical contaminants as an energy source, rendering the contaminants harmless or less toxic products in most cases [30]. Compost usually contains heavy metals based on their initial raw materials. These heavy metals (micronutrients) are required by the plant for perfect growth and they are absorbed by plants during the fertilizing process; but in large quantities, they can cause phytotoxicity.

The beneficial effects of adding Biochar to composts were: increased $\mathrm{pH}, \mathrm{CEC}$, soil water retention, nutrient retention, improved soil structure, soil aeration, hydraulic conductivity and adsorption of heavy metals [31-32]. The carboxyl groups (functional groups) found in Biochar can explain the high CEC, liming effect and high charge density of Biochar [12]. The physical structure characterized by a network of micro-, meso and macro pores allows for improved soil structure by increasing aeration, decreasing bulk density and reducing the soils tensile strength [33]. Biochar addition also had a large effect on the microbial activity, soil organic matter (SOM) levels [34], C cycling [35], and nitrogen $(\mathrm{N})$ dynamics [12]. The total surface area in biochar allows for "storage space" of different nutrients and organic compounds that optimizes microbial growth [12]. Biochar is commonly applied for environmental purposes such as (i) managing pollution and eutrophication risks, (ii) re-vegetation of degraded land, and (iii) $\mathrm{C}$ sequestration [36].

\section{Conclusions}

Overall conclusion is that combining both Effective Microorganisms (EM) and Biochar under the most preferred Berkeley composting technique accelerated the rate of decomposition of the organic materials hence it was the most effective process of composting and on top of that, EM and Biochar had positive impacts on the chemical and physical properties of compost manure produced from these treatments in Kakamega central sub county, Kenya. This can sustainably restore the soil fertility of depleted soils hence ensuring neutrality in land degradation, thus increasing crop production that will ensure food security of the ever-increasing population in Kakamega central sub county. Composts produced from the treatments contained both Macro and micro nutrients that are within the recommended ranges. EM and Biochar had positive impacts on the chemical and physical properties of composts.

\section{Conflict of Interest}

The authors declare that there is no conflict of interest. 


\section{References}

[1] A. Sasson, Food security for Africa: an urgent global challenge, Agriculture \& Food Security. 1(1) (2012) 2 .

[2] R. Lal, Challenges and opportunities in soil organic matter research, European Journal of Soil Science. 60(2) (2009) 158-169.

[3] N.D. Chauvin, F. Mulangu, G. Porto, Food Production and Consumption Trends in SubSaharan Africa: Prospects for the Transformation of the Agricultural Sector WP 2012-011. United Nations Development Programme, Regional Bureau for Africa.

[4] A.F. Ngome et al., Maize productivity and nutrient use efficiency in Western Kenya as affected by soil type and crop management, International Journal of Plant Production. 7(3) (2013) 51 7-536.

[5] A. Bationo et al., Soil organic carbon dynamics, functions and management in West African agro-ecosystems, Agricultural systems. 94(1) (2007) 13-25.

[6] J. Mugwe et al., Maize yields response to application of organic and inorganic input under onstation and on-farm experiments in central Kenya, Experimental Agriculture. 45(1) (2009) 4759.

[7] W. Negassa, H. Gebrekidan, D.K. Friesen, Integrated Use of Farmyard Manure and NP fertilizers for Maize on Farmers' Fields, Journal of Agriculture and Rural Development in the Tropics and Subtropics. 106(2) (2005) 131-141.

[8] K. Killham, Integrated soil management - moving towards globally sustainable agriculture, Journal of Agricultural Science. 149 (2011) 29-36.

[9] R.D. Raabe, The rapid composting method. Cooperative extension, University of California, Division of Agriculture and Natural resources leaflet, 2001.

[10] FAO (2012), Soil Management. Compost Production and Use in Tropical and sub Tropical environments.

[11] P.S.J. Mustonen, M. Oelberman, D.C.L. Kass, Production of Phaseolus vulgaris L. Genotypes with Tithonia diversifolia (Hemsl.) Gray and Cajanus cajan (L.) Millsp, Agronomy. 3 (2013) 232-247.

[12] J. Lehmann et al., Biochar effects on soil biota-a review, Soil Biology and Biochemistry. 43(9) (2011) 1812-1836.

[13] T. Sonoki et al., Impacts of Biochar Addition on Methane and Carbon Dioxide Emissions during Composting of Cattle Manure. Asia Pacific Bioinformatics Conference, 2011.

[14] C. Wang et al., Insight into the effects of biochar on manure composting: evidence supporting the relationship between $\mathrm{N}_{2} \mathrm{O}$ emission and denitrifying community, Environmental Science and Technology. 47 (2013) 7341-7349.

[15] C. Liang, K.C. Das, R.W. McClendon, The influence of temperature and moisture contents regimes on the aerobic microbial activity of a biosolids composting blend, Bioresource Technology. 86 (2003) 131-137.

[16] C. Steiner et al., Reducing nitrogen loss during poultry litter composting using biochar, Journal of Environmental Quality. 39 (2010) 1236-1242.

[17] Y.X. Chen et al., Effects of bamboo charcoal and bamboo vinegar on nitrogen conservation and heavy metals immobility during pig manure composting, Chemosphere. 78 (2010) 11771181. 
[18] B.O. Dias et al., Use of biochar as bulking agent for the composting of poultry manure: effect on organic matter degradation and humification, Bioresource Technology. 101 (2010) 12391246.

[19] J.A. Rota, P. Wandahwa, D.O. Sigunga, Land evaluation for soybean (Glycine max L. Merrill) production based on kriging soil and climate parameters for the Kakamega District, Kenya, Journal of Agronomy. 5 (2006) 142-150.

[20] J.C. Ostos et al., Substitution of peat for municipal solid waste- and sewage sludge-based composts in nursery growing media: Effects on growth and nutrition of the native shrub Pistacia lentiscus L., Biores. Technol. 99 (2008) 1793-1800.

[21] M.A. Hubbe, M. Nazhad, C. Sánchez, Composting as a way to convert cellulosic biomass and organic waste into high-value soil amendments: A review, BioResources. 5(4) (2010) pp. 2808-2854.

[22] C. Hu, Y. Qi, Long-term Effective Microorganisms application promote growth and increase yields and nutrition of wheat in China, European Journal of Agronomy. 46 (2013) 63-67.

[23] L. Copperband, The Art and Science of Composting, A resource for farmers and compost producers. University of Wisconsin-Madison, Center for Integrated Agricultural Systems, 2002.

[24] P.N. Chandi, EM: A microbial product for sustainable agriculture, in: E.N. Savala, M.N. Omare, P.L. Woomer (Eds.), Forum for Organic Resource Management and Agricultural Technologies. FORMAT, Nairobi, Kenya, Chapter 18, 2003.

[25] M.M. Alley, B. Vanlauwe, The role of fertilizers in integrated plant nutrient management. Paris: International Fertilizer Industry Associationand development of simple methods of assessment. Agricultural Ecosystemsand Environment. 94 (2009) 289-298.

[26] E. Erhart, W. Hartl, Compost Use in Organic Farming, in: E. Lichtfouse (Ed.), Genetic Engineering, Biofertilisation, Soil Quality and Organic Farming, New York: Springer Science, 2010, pp. 311-246.

[27] E. Mowa, E. Maass, The effect of sulphuric acid and effective micro-organisms on the seed germination of Harpagophytum procumbens (devil's claw), South African Journal of Botany. 83 (2012) 193-199.

[28] P. Saravanan, S.S. Kumar, C. Ajithan, Eco-friendly practice of utilization of food wastes, International Journal of Pharmaceutical Sciences Innovation. (2013) 14-17.

[29] M.L.C. Jusoh, L.A. Manaf, P.A. Latiff, Composting of rice straw with effective microorganisms (EM) and its influence on compost quality, Iranian Journal of EnvironMental Health Science \& Engineering. 10(1) (2013) 17-17.

[30] M.S. Akhtar, B. Chali, T. Azam, Bioremediation of arsenic and lead by plants and microbes from contaminated soil, Research in Plant Sciences. 1(3) (2013) 68-73.

[31] C.R. Anderson et al., Biochar induced soil microbial community change: implications for biogeochemical cycling of carbon, nitrogen and phosphorus, Pedobiologia. 54(5) (2011) 309320 .

[32] H. Schmidt et al., Biochar and biochar-compost as soil amendments to a vineyard soil: Influences on plant growth, nutrient uptake, plant health and grape quality, Agriculture, Ecosystems \& Environment. 191 (2014) 117-123.

[33] A. Downie, A. Crosky, P. Munroe, Physical properties of biochar, Biochar for environmental management: Science and technology, 2009, pp. 13-32. 
[34] J. Tian et al., Biochar affects soil organic matter cycling and microbial functions but does not alter microbial community structure in a paddy soil, Science of the Total Environment. 556 (2016) 89-97.

[35] N.S. Bolan et al., Stabilization of carbon in composts and biochars in relation to carbon sequestration and soil fertility, Science of the Total Environment. 424 (2012) 264-270.

[36] P. Blackwell, G. Riethmuller, M. Collins, Biochar application to soil, in: Biochar for environmental management: science and technology, 2009, pp. 207-226. 